\begin{tabular}{r|l|l|l}
$\begin{array}{c}\text { Case Reports in } \\
\text { Oncology }\end{array}$ & $\begin{array}{l}\text { Case Rep Oncol 2011:4:175-177 } \\
\text { DOl: 10.1159/000327363 }\end{array}$ & $\begin{array}{l}\text { Published online: } \\
\text { March 29, 2011 }\end{array}$ & $\begin{array}{l}\text { O 2011 S. Karger AG, Basel } \\
\text { ISSN 1662-6575 } \\
\text { www.karger.com/cro }\end{array}$ \\
\hline
\end{tabular}

This is an Open Access article licensed under the terms of the Creative Commons AttributionNonCommercial-NoDerivs 3.0 License (www.karger.com/OA-license), applicable to the online version of the article only. Distribution for non-commercial purposes only.

\title{
Leser-Trélat Sign without Internal Malignancy
}

\author{
Gilles Safa Laure Darrieux \\ Department of Dermatology, Centre Hospitalier de Saint-Brieuc, Saint-Brieuc, \\ France
}

\section{Key Words}

Leser-Trélat sign · Paraneoplastic syndrome · Seborrheic keratoses

\begin{abstract}
Leser-Trélat sign is characterized by the abrupt appearance of multiple seborrheic keratoses in association with underlying malignant disease. A case of Leser-Trélat sign in a 66-year-old healthy woman is presented. Evaluation and follow-up for the development of malignancy over a 2-year period failed to reveal any evidence of malignancy. To date, almost all cases of Leser-Trélat sign have been reported in association with an underlying malignancy. It is less known that Leser-Trélat sign can also occur in healthy individuals in the absence of internal malignancy.
\end{abstract}

\section{Introduction}

Leser-Trélat sign, or eruptive seborrheic keratosis, is defined as the association of the abrupt appearance of multiple seborrheic keratoses, often pruritic, with an underlying internal malignancy [1]. This sign has been regarded as a rare but reliable cutaneous marker of internal malignancy. The pathogenesis of Leser-Trélat sign is still unknown. Leser-Trélat sign is not widely accepted as a paraneoplastic syndrome because seborrheic keratoses and cancer are common findings in the elderly.

We report on a patient who, at first glance, might have been diagnosed as having Leser-Trélat sign, if such a paraneoplastic disorder actually exists.

\section{Case Report}

A healthy 66-year-old Caucasian woman presented with multiple itchy seborrheic keratoses distributed over her trunk. She reported that the lesions had developed over a period of less than 1 year (fig. 1). Her past medical history and family history were unremarkable.

On examination, no other cutaneous lesions were detected, and general physical examination was unremarkable. Histological examination confirmed the diagnosis of the lesions as seborrheic keratoses. The cutaneous findings were consistent with a possible sign of Leser-Trélat. 
To search for an underlying malignancy, the following investigations were performed and found to be normal: complete blood count, urea and electrolytes, liver function tests, plasma calcium, proteins and electrophoresis, chest X-ray, mammography, mammary ultrasound, upper gastrointestinal endoscopy and colonoscopy. Abdominal and pelvic computed tomography scan revealed a fibromatous uterus, which was confirmed by ultrasound examination. Although the patient had never experienced postmenopausal vaginal bleeding, measurement of endometrial thickness was performed and showed an endometrial width of $2 \mathrm{~mm}$, ruling out endometrial cancer. No other abnormality was detected upon complete gynecological examination. Otolaryngological examinations were also negative. During a follow-up period of 2 years, the seborrheic keratoses remained unchanged. The patient has remained in good health without any specific signs or symptoms suggestive of an underlying malignancy.

\section{Discussion}

Although there are a high number of case reports in the literature, the existence of the Leser-Trélat sign is questioned by some authors $[2,3]$. Commonly associated malignancies include adenocarcinomas from diverse sites, and the most frequently reported site is the gastrointestinal tract. Other types of malignancy reported in connection with this sign have been hematopoietic neoplasms, and breast and lung cancers, among others [1]. A Leser-Trélat-like eruption has also been described in nonmalignant conditions such as human immunodeficiency virus infection [4], generalized dermatitis [5], and heart transplant [6]. The average age at onset of LeserTrélat sign is about 60 years. However, young patients with Leser-Trélat sign have also been reported [7]. The cause of the Leser-Trélat sign is unknown. This paraneoplastic syndrome is thought to be related to a tumor-derived circulating growth factor which induces epidermal proliferation and results in the rapid development of multiple seborrheic keratoses [8]. The importance of the immunohistochemical analyses of endogenous mediators such as epidermal growth factor receptor protein and the consequent high risk of underlying malignancies have been described [9].

In recent years, new molecular genetic insights into seborrheic keratoses have been gained. A genetic predisposition for multiple seborrheic keratoses is thought to exist. Molecular genetics has shown that somatic fibroblast growth factor receptor 3 (FGFR3) and phosphatidylinositol 3-kinase catalytic subunit a (PIK3CA) mutations are involved in the pathogenesis of seborrheic keratoses, although the precise mechanisms and the signaling pathways responsible are still unclear. Yet, one would expect that, unlike sporadic seborrheic keratoses, the seborrheic keratoses in Leser-Trélat sign would not be associated with any FGFR3 or PIK3CA mutations, because activation of involved signal pathways would be due to an excess of ligands secreted by the cancer cells [10]. Another potential mechanism for these lesions relates to the possible role of human papillomavirus as an etiological factor in seborrheic keratoses, especially in immunocompromised patients with human immunodeficiency virus infection [4].

In conclusion, this case describes Leser-Trélat sign in a healthy woman. From the data available in the literature, it is not possible either to demonstrate or to reject definitively the existence of this entity. Hence, patients with a history of acute onset and/or rapid increase in size and number of multiple seborrheic keratoses should also in the future undergo a screening program in order to rule out an underlying cancer. Indeed, cutaneous symptoms may precede, accompany or follow the discovery of the malignancy. However, it is less known that Leser-Trélat sign can also occur in healthy individuals in the absence of internal malignancy. Therefore, this case of a 2-year history of Leser-Trélat sign without signs of internal malignancy should be noted. 


\begin{tabular}{c|l|l|l}
$\begin{array}{c}\text { Case Reports in } \\
\text { OICOlOy) }\end{array}$ & $\begin{array}{l}\text { Case Rep Oncol 2011;4:175-177 } \\
\text { DOI: } 10.1159 / 000327363\end{array}$ & $\begin{array}{l}\text { Published online: } \\
\text { March 29, 2011 }\end{array}$ & $\begin{array}{l}\text { ○ } 2011 \text { S. Karger AG, Basel } \\
\text { ISSN 1662-6575 } \\
\text { www.karger.com/cro }\end{array}$ \\
\hline
\end{tabular}

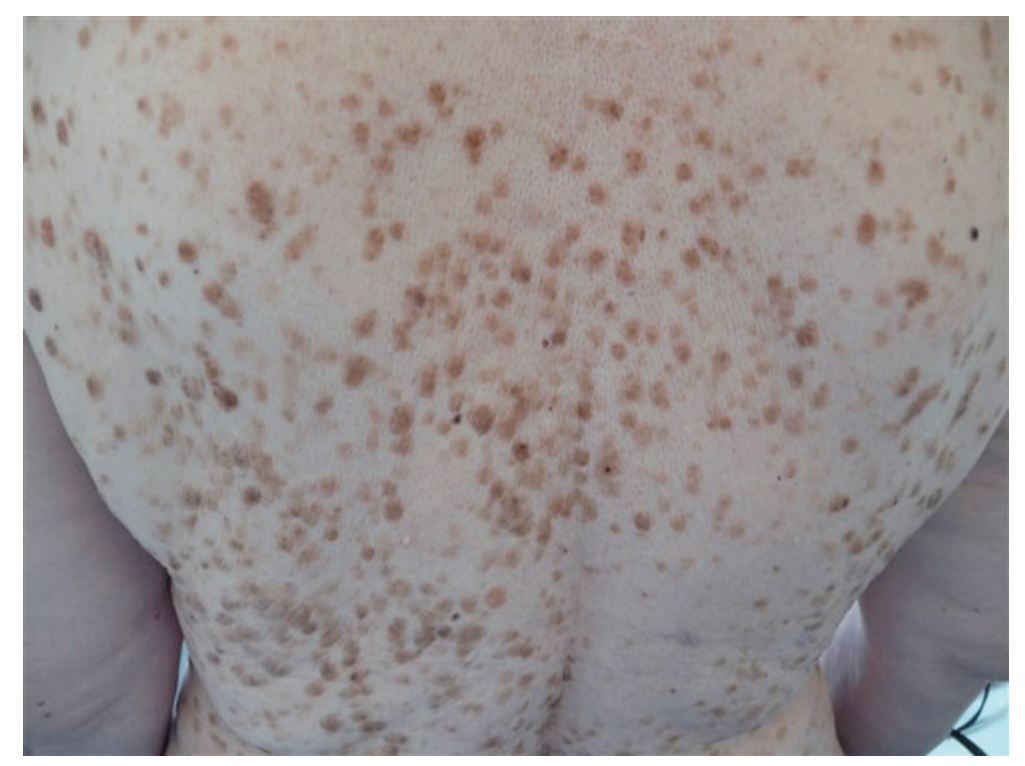

Fig. 1. Sudden onset of multiple seborrheic keratoses on the back.

\section{References}

1 Schwartz RA: Sign of Leser-Trélat. J Am Acad Dermatol 1996;35:88-95.

2 Rampen FHJ, Schwengle LEM: The sign of Leser-Trélat: does it exist? J Am Acad Dermatol 1989;21:50-55.

-3 Grob JJ, Rava MC, Gouvernet J, Fuentes P, Piana L, Gamerre M, Sarles JC, Bonerandi JJ: The relation between seborrheic keratoses and malignant solid tumours. A case-control study. Acta Derm Venereol 1991;71:166169.

4 Inamadar AC, Palit A: Eruptive seborrhoeic keratosis in human immunodeficiency virus infection: a coincidence or 'the sign of Leser-Trélat'? Br J Dermatol 2003;149:435-436.

5 Schwengle LE, Rampen FH: Eruptive seborrheic keratoses associated with erythrodermic pityriasis rubra pilaris. Possible role of retinoid therapy. Acta Derm Venereol 1988;68:443-445.

6 Hsu C, Abraham S, Campanelli A, Saurat JH, Piguet V: Sign of Leser-Trélat in a heart transplant recipient. Br J Dermatol 2005;153:861-862.

7 Barron LA, Prendiville JS: The sign of Leser-Trélat in a young woman with osteogenic sarcoma. J Am Acad Dermatol 1992;26:344-347.

8 Ellis DL, Kafka SP, Chow JC, Nanney LB, Inman WH, McCadden ME, King LE Jr: Melanoma, growth factors, acanthosis nigricans, the sign of Leser-Trélat, and multiple acrochordons: a possible role of alpha-transforming growth factor in cutaneous paraneoplastic syndromes. N Engl J Med 1987;317:1582-1587.

9 Ponti G, Luppi G, Losi L, Giannetti A, Seidenari S: Leser-Trélat syndrome in patients affected by six multiple metachronous primitive cancers. J Hematol Oncol 2010;3:2.

10 Hafner C, Vogt T: Seborrheic keratosis. J Dtsch Dermatol Ges 2008;6:664-677. 